This is a post-peer-review, pre-copyedit version of an article published in Clinical Drug Investigation. The final authenticated version is available online at: https://doi.org/10.1007/s40261$\underline{020-00904-8}$ 


\section{Osteoporosis Economic burden of disease in Italy}

Andrea Marcellusi ${ }^{1}$, Maria Assunta Rotundo ${ }^{1}$, Claudia Nardone ${ }^{1}$, Paolo Sciattella $^{1}$, Simone Gazzillo ${ }^{1}$, Maurizio Rossini ${ }^{2}$, Mario Barbagallo ${ }^{3}$, Amalia Antenori $^{4}$, Domenico Valle ${ }^{4}$, Francesco Saverio Mennini ${ }^{1}$

1.Faculty of Economics, Economic Evaluation and HTA (EEHTA), CEIS, University of Rome "Tor Vergata", Via Columbia 2, 00133, Rome, RM, Italy.

2. Rheumatology Section, Department of Medicine, University of Verona, Verona, Italy.

3. Geriatric Unit, Department of Internal Medicine and Medical Specialties, University of Palermo, 90127 Palermo, Italy.

4. Eli Lilly spa, 00144 Rome, Italy

Corresponding author: Dr Andrea Marcellusi

Institute: Economic Evaluation and HTA (EEHTA) - Faculty of Economics

University: University of Rome "Tor Vergata", Rome, Italy.

Address: Via Columbia 2

Postal code: 00133 Rome - Italy

E-mail: andrea.marcellusi@uniroma2.it 


\begin{abstract}
Background and objective: Today osteoporosis is the most common bone disease and important public health problem in all developed countries. The objective of this study was to estimate the costs associated with the management and treatment of osteoporosis in order to assess the economic burden in Italy for 2017, in terms of direct medical costs and social security costs.

Methods: A Cost of Illness model was developed to estimate the average cost per year sustained by the NHS (National Health Service) and Social Security System in Italy. A Systematic Literature Review was performed to obtain epidemiological, direct and indirect costs parameters where available. Hospitalization costs were calculated considering the administrative database of Hospitalization available in Italy between 2008-2016. Patients were enrolled in the analysis if they report the subsequent inclusion criteria: age $\geq 45$ years and presence of osteoporosis in primary or secondary diagnosis (ICD9-CM 733.0) and/or presence of a major fracture in primary or secondary diagnosis (excluding road accidents) in the following locations: spine (codes ICD9-CM: 805;806), femur (codes ICD9-CM: 820; 821), radiusm and ulna (codes ICD9-CM: 813.4; 813.5), humerus (codes ICD9-CM: 812.0-812.5), pelvis (code ICD9-CM: 808), tibia and fibula (codes ICD9-CM: 823), ankle (code ICD9: 824) and ribs (codes ICD9-CM: 807.0; 807.1).. Costs were estimated considering the DRG (Diagnosis-related group) national tariff associated with each hospitalisation. Finally, the administrative databases of the National Social Security Institute (INPS) (2009-2015) were analysed for the estimate the pension and disability costs from the social perspective.
\end{abstract}

Results: The model estimated an average annual economic burden of osteoporosis in Italy of $€ 2.2$ billion. Of this cost, $80 \%$ ( $€ 1.8$ billion) was associated to hospitalizations, $16 \%$ (€ 0.35 billion) for pharmacological treatments, $3 \%$ (€ 0.07 billion) to ambulatory visits, and $1 \%$ (€ 0.01 billion) to social security costs. The average yearly cost per patient was equal to $€ 8,691(€ 8,591$ for hospitalizations). Analysing severe patients, hospitalization costs increase to $€ 12,336$ ( $+44 \%$ if compared to general osteoporosis patients).

Conclusions: The analysis showed that osteoporosis represents one of the main health problems in Italy and the ability to maintain patients in a non-severe health state could decrease the economic burden from both NHS and social perspective. 


\section{Key Points:}

- Overall, the economic burden associated to the osteoporosis patients in Italy was equal to $€$ 2.2 billion from the NHS and social security system perspective;

- $81 \%$ ( $€ 1.8$ billion) of the total economic burden was associated to hospitalization costs ( $63 \%$ related to hospitalizations due to fractures, $37 \%$ to hospitalizations due to other causes), $16 \%$ ( $€ 351$ million) to pharmacological treatments cost, 3\% (€ 71 million) to ambulatory visits and $1 \%$ ( $€ 13$ million) to social security cost;

- the average annual hospitalization cost per patient with severe osteoporosis (subjects aged $\geq$ 45 years with osteoporosis in primary or secondary diagnosis and with a fracture, the subjects aged $\geq 45$ years with two fractures and those aged $\geq 45$ years with three or more fractures.) was $€ 12,336$ ( $+\mathrm{XX} \%$ if compared to non severe patients $€ 8,591$ )

\section{Compliance with Ethical Standards.}

Funding: This study received an unrestricted institutional grant from the pharmaceutical company Eli Lilly Italy.

Conflicts of interest: AM, MAR, CN, PS, SG, MR, MB and FSM had no conflict of interest. AA and DV are employee of Eli Lilly Italy 


\section{Introduction}

Osteoporosis is a systemic disease characterized by low bone mass and by qualitative alterations of macro- and micro-architecture of the skeletal tissue, such as to increase bone fragility and, therefore, the risk of fracture even for low/medium energy traumas [1].

The most frequent osteoporotic fractures are those of the wrist, humerus, ribs, pelvis, spine column and femur. These fractures can cause complex disabilities, morbidity, reduced quality of life and functional limitation. Moreover, spine and hip fractures increase the relative risk of mortality [2].

Although osteoporosis has been historically considered a disease mainly affecting postmenopausal women, in recent years it has been shown that fragility fractures are a statistically significant event in men [3]. Conventionally, this disease occurs into two distinct forms:

1. Primary osteoporosis: occurring after menopause (type I osteoporosis) or with ageing (type II osteoporosis).

2. Secondary osteoporosis: due to the presence of other clinical conditions (endocrine-metabolic diseases, myelo-and lymphoproliferative diseases, conditions associated with intestinal malabsorption, rheumatic diseases, kidney diseases, organ transplantation) or to the taking of certain medication in the medium-long term (glucocorticoids, aromatase inhibitors).

The term idiopathic osteoporosis, on the other hand, identifies a form of osteoporosis for which there is no clear cause that can explain the onset of the disease [4-6]. The incidence and prevalence of osteoporotic fractures increase exponentially with age [7], generating significant social and economic costs. Certainly, gathering exact information and data on welfare flows and related expenditure is a starting point for the improvement of healthcare programmes and the development of cost containment policies.

In Italy, during the last decade, the demographic structure of the population increases the number of osteoporosis patients due to the ageing population. It was estimated that more than the half of postmenopausal women aged 50 and older in Italy have osteoporosis on the basis of the most recent criteria [8]. The increasing level of osteoporosis disease represents one of the main in issue not only from the NHS perspective but also from a social perspective. In Italy, information on the burden of osteoporosis across age groups, sex, and fracture sites is also lacking.

The objective of this study was to develop a Cost of illness (CoI) model able to estimate the costs associated with the management and treatment of osteoporosis in Italy in one year, from the perspective of the National Health Service (NHS) and that of the national social security system. 


\section{Methods}

\subsection{Study design}

The CoI model was developed starting from the prevailing patients. The reference year for the analysis was 2017.

The perspective used was that of the NHS and the national social security system. Therefore, direct costs (the costs directly related to the diagnosis and treatment of the disease) and social security costs (the costs related to disability allowances and pensions paid, under certain conditions, to patients) respectively were estimated.

Epidemiological and cost data were obtained by conducting a systematic review of the literature (SRL) and by consulting the administrative database of hospital discharge records (HDR) and the database of the National Social Security Institute (INPS).

\subsection{Systematic literature review}

In order to find the national epidemiological and cost data available from the literature, in January 2019, a SLR was conducted, using different search engines (PubMed, EpiCentro) and consulting Italian health economics journals (Farmacoeconomia e Percorsi Terapeutici, PharmacoEconomics Italian Research Articles, Global and Regional Health Technology Assessment). Articles relating to the past 5 years have been reviewed.

In accordance with the recommended guidelines for the systematic analysis of scientific literature [9], the systematic process was divided into 4 stages: identification, screening, eligibility and inclusion.

In the first stage (identification), the search terms to be used to extract articles from each single consulted electronic database were identified:

- Pubmed:

- Cost items:

(economic evaluation[Title/Abstract] OR cost[Title/Abstract] OR burden[Title/Abstract] OR economic impact[Title/Abstract]) AND (osteoporosis[Title/Abstract] OR BMD[Title/Abstract] OR Osteoarthritis[Title/Abstract] OR OSTC[Title/Abstract] OR “Osteoporosis"[Mesh])

- Epidemiological articles: (epidemiology[Title/Abstract] OR epidemiology[MeSH Terms] OR prevalence[MeSH Terms]) AND osteoporosis[MeSH Terms]

- Pharmaeconomics and therapeutic pathways: COST + OSTEOPOROSIS 
- Google scholar: EPIDEMIOLOGY OR PREVALENCE + COST OR BURDEN + OSTEOPOROSIS

- EPICENTRO: COST + EPIDEMIOLOGY + OSTEOPOROSIS

- Pharmacoeconomics Italian Research Articles: EPIDEMIOLOGY OR PREVALENCE + COST OR BURDEN + OSTEOPOROSIS

- Global \& Regional Health Technology Assessment: EPIDEMIOLOGY OR PREVALENCE + COST OR BURDEN + OSTEOPOROSIS

This first stage identified 232 articles through PubMed and 238 articles through the other electronic databases mentioned above.

In the second stage (screening), duplicates were removed from the total number of identified articles. This process is necessary when the SLR is carried out on more than one electronic database.

In the third stage (eligibility), two researchers independently reviewed the studies, using the title, abstract or extended text, in order to include (fourth stage) only the studies meeting at least one of the following inclusion criteria:

- nationwide studies containing data on the direct costs of the disease, examined from the perspective of the NHS, and expressed in monetary values by hospital groups related to the disease (DRG) and outpatient rates;

- nationwide observational studies on epidemiological and/or cost data for osteoporosis;

- national or international studies reporting significant nationwide data for osteoporosis.

At the end of the review process, 4 articles were included in the analysis (Figure 1). 
Figure 1 PRISMA Flow chart
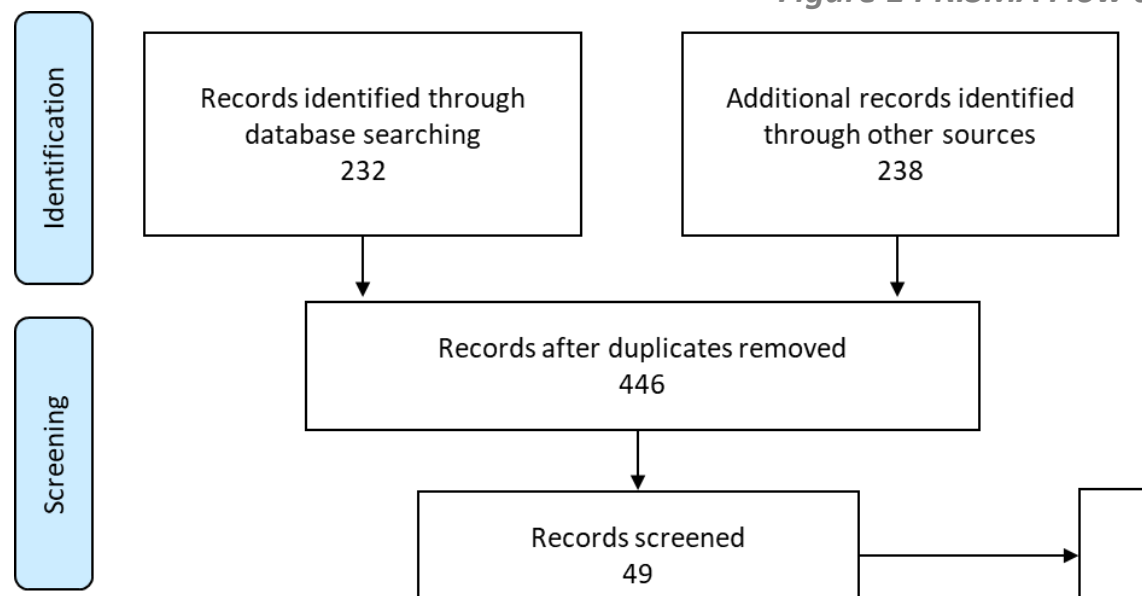

Records after duplicates removed 446
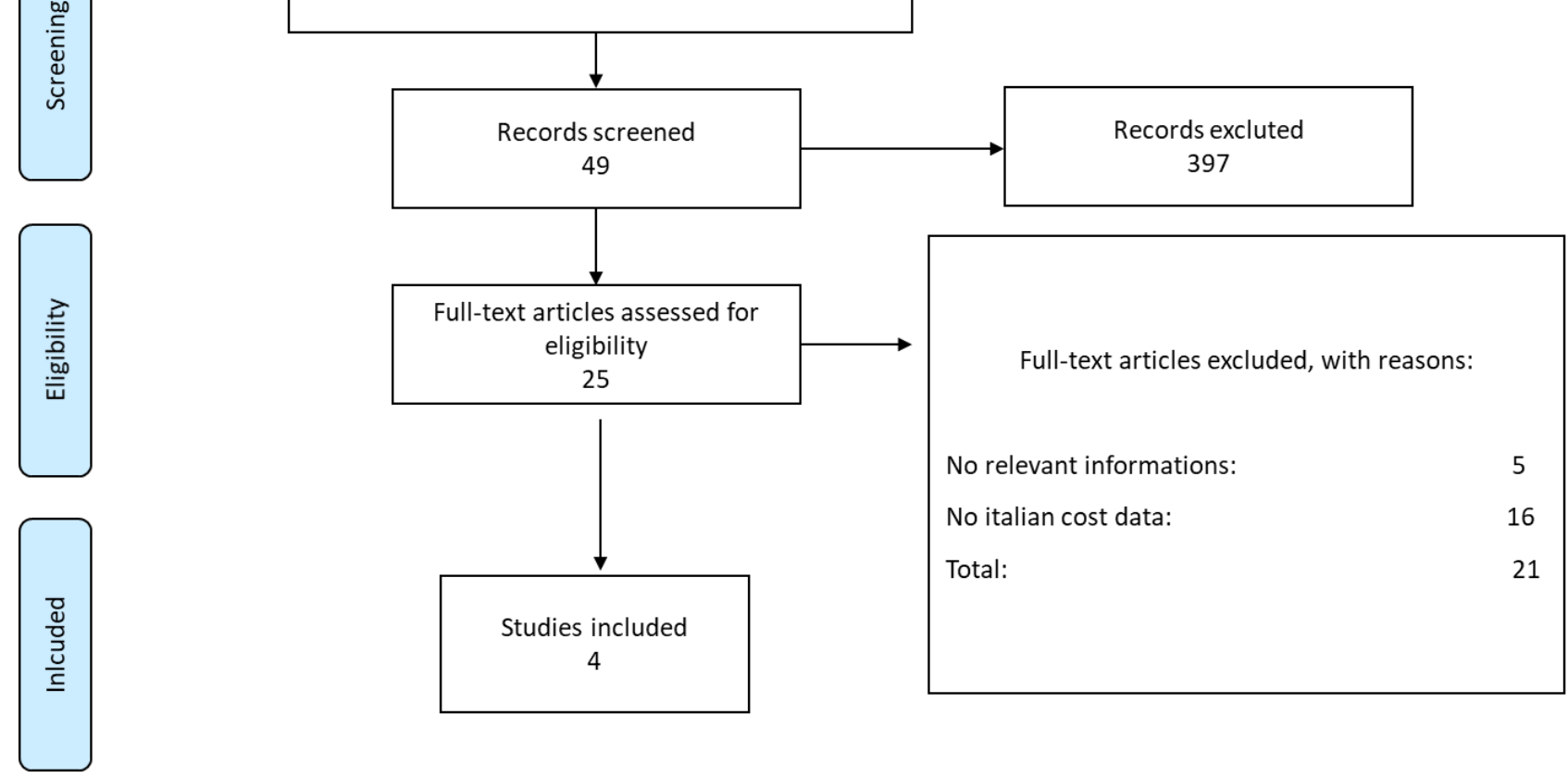


\subsection{Querying administrative databases}

In order to estimate the hospitalization costs related to osteoporosis disease, it was developed an analysis on the administrative database of the Hospital Discharge Records (HDR) for the period 2008-2016.HDR collects all hospitalizations events occurred in all public and private institutes of Italy. The discharge records include the patient's demographic (gender, age, education, residence) and clinical information, the diagnosis and the main and secondary procedures ( 5 fields) as set out in the International Classification of Diseases (ICD-9-CM). Costs were estimated considering the DRG (Diagnosis-related group) national tariff associated with each hospitalisation

Through the analysis conducted on the HDR, it was possible to select the number of subjects with osteoporosis, according to the following inclusion criteria: age $\geq 45$ years and presence of osteoporosis in primary or secondary diagnosis (ICD9-CM 733.0) and/or presence of a major fracture in primary or secondary diagnosis (excluding road accidents) in the following locations: spine (codes ICD9-CM: 805;806), femur (codes ICD9-CM: 820; 821), radius and ulna (codes ICD9-CM: 813.4; 813.5), humerus (codes ICD9-CM: 812.0-812.5), pelvis (code ICD9-CM: 808), tibia and fibula (codes ICD9-CM: 823), ankle (code ICD9: 824) and ribs (codes ICD9-CM: 807.0; 807.1).

The subjects were broken down into three age groups $(<60,60-74, \geq 75)$. The national average annual number of admissions and the average annual expenditure for subjects with osteoporosis were obtained as the average value of the number of admissions and the expenditure estimated for the nine years being analysed.

A further objective of this study was to focus on the costs related to patients with severe osteoporosis, where severe means the presence of a previous fracture in the patient with osteoporosis. Using the HDR information database analysed for the period 2008-2016, it was possible to select all the subjects aged $\geq 45$ years with osteoporosis in primary or secondary diagnosis and with a fracture, the subjects aged $\geq 45$ years with two fractures and those aged $\geq 45$ years with three or more fractures.

The estimate of social security costs was calculated by consulting the databases of the National Social Security Institute (INPS) for the period 2009-2015. The national social security system in Italy aims to protect workers and family members in the event of (partial or total) loss of working capacity due to illness. This protection function is carried out through the payment of Disability Benefits (DB) or Incapacity Pension (IP). All categories of workers registered with the Italian National Social Security Institute (INPS) have the right to receive DB or IP in case of an accident or illness and after five years of welfare insurance contributions [10].

The DB is a financial benefit for all categories of workers registered with INPS (mainly private sector employees and self-employed workers), with five years of social security contributions, and with workability reduced to less than one-third due to physical or mental illness. It is necessary to 
apply for it, and if the medical board approves, it is not required to cease work. The allowance is recognized for a period of three years and is confirmable for periods of the same duration. After three consecutive awards, it is automatically confirmed. This type of allowance is funded and paid for thirteen months by INPS. The IP is a financial benefit for all categories of workers registered with INPS to which has been recognized an absolute and permanent inability to work. Also in this case, five years of social welfare contributions, and a specific application are necessary. Retirement from work is required. This type of pension is funded and paid by INPS and it is paid for thirteen months, too $[10]$.

All patients with a recognised Disabilty Benefits (DB) - paid to individuals with a degree of disability between $67 \%$ and $99 \%$ - or an Incapacity Pension (IP) - paid to individuals with a degree of disability equal to $100 \%$ - were identified considering the subjects diagnosed with osteoporosis and/or the subjects aged $>60$ years with a fracture, in primary or secondary diagnosis; these patients were subsequently broken down according to the presence or absence of comorbidity in the secondary diagnosis. As in the case of hospitalizations, the average annual number of accepted applications and the related average annual expenditure were obtained as the average of the accepted applications and the estimated expenditure in the seven years being analysed.

A variability measure of the total economic burden was estimated considering: the minimum and maximum parameter reported in table 1 for drug and specialistic visits, the minimum and maximum annual hospitalization cost registered between 2008 - 2016, the minimum and maximum annual social security cost between $2009-2015$. 


\section{Results}

\subsection{Estimate of the population with osteoporosis}

According to the information found in the literature $[11,12]$, the average age of the patients suffering from osteoporosis in Italy is 50 years, specifically 45 years for women and 55 years for men.

With regard to the prevalence data available in the literature, an average value for women (base case) of $20.95 \%$ ( $\min =18.50 \%$; $\max =23.40 \%)[11,12]$, and an average value for males of $8.45 \%(\min =6.90 \%[11] ; \max =10 \%[12])$ have been estimated.

Applying the average prevalence values obtained from the literature to the population living in Italy as of 1 January 2017 aged $\geq 45$ years (16,701,772 women and 9,669,652 men) [13], the number of people suffering from osteoporosis in Italy in 2017 was 4,316,107 subjects $(3,499,021$ women and 817,086 men).

The prevalence values clearly show that the majority of individuals with osteoporosis are female $(81 \%)$.

The consequences of osteoporosis are measurable, among other elements, in the number of fractures that the patient undergoes due to the microarchitectural deterioration of the bone tissue caused by the disease and that exposes the patient to a greater risk of fracture.

Not all the patients suffering from osteoporosis actually experience a fracture. The average annual number of fractures identified analysing the national HDR administrative database for the period 2008-2016 was equal to 215,302 (from an estimated number equal to 207,884 patients). With reference to the location of the fracture, $53.9 \%(115,972)$ of the total fractures were hip fractures, $10.3 \%(22,120)$ humerus fractures, 9.1\% (19,575) spinal column fractures, $8.3 \%(17,785)$ ribs fractures, $6.3 \%(13,593)$ fractures of the radius or ulna, $5 \%(10,764)$ pelvis fractures, $4.1 \%(8,867)$ ankle fractures and $3.1 \%(6,626)$ fibula or tibia fractures.

However, the number of fractures obtained is underestimated. With the data at our disposal, it has not been possible to trace the patients who are not hospitalized, due to the fact that they might have been treated only in the emergency department or they might not have been treated at all in an emergency department, as it often happens with spine fractures.

The epidemiological parameters identified through to the systematic review process and the analysis of the HDR database are reported in table 1. 


\begin{tabular}{|c|c|c|c|c|c|c|}
\hline $\begin{array}{l}\text { EPIDEMIOLOGICAL } \\
\text { PARAMETERS }\end{array}$ & BASE CASE & MIN & MAX & $\begin{array}{l}\text { OSTEOPOROTIC } \\
\text { POPULATION }\end{array}$ & SOURCE & NOTES \\
\hline $\begin{array}{l}\text { Women population } \\
\text { aged } 45+\text { resident in } \\
\text { Italy at } 1 \text { st January } \\
2017\end{array}$ & $16,701,772$ & - & - & - & [13] & - \\
\hline $\begin{array}{c}\text { Men population aged } \\
55+\text { resident in Italy at } \\
\text { 1st January } 2017\end{array}$ & $9,669,652$ & - & - & - & [13] & - \\
\hline $\begin{array}{l}\text { Prevalence of } \\
\text { osteoporosis in } \\
\text { women }\end{array}$ & $20.95 \%$ & $18.50 \%$ & $23.40 \%$ & $3,499,021$ & {$[11,12]$} & Age: $40+; 50+$ \\
\hline $\begin{array}{c}\text { Prevalence of } \\
\text { osteoporosis in men }\end{array}$ & $8.45 \%$ & $6.90 \%$ & $10 \%$ & 817,086 & {$[11,12]$} & Age: $50+; 60+$ \\
\hline $\begin{array}{c}\text { Total osteoporotic } \\
\text { population in Italy in } \\
2017 \\
\end{array}$ & - & - & - & $4,316,107$ & - & - \\
\hline $\begin{array}{c}\text { Average annual } \\
\text { number of fractures }\end{array}$ & 215,302 & - & - & - & - & - \\
\hline
\end{tabular}

\subsection{Estimated costs associated with patients with osteoporosis}

The direct health costs considered in the analysis were referred to the cost of drugs, ambulatory visits and hospitalizations.

The cost of drugs and ambulatory visits has been obtained through the average cost estimates emerging from the literature $[12,14,15]$. These average values have been subsequently re-valued to 2017 [16].

By applying the average costs per patient to the total number of patients with osteoporosis in Italy in 2017 , it was possible to obtain a total cost for drugs and ambulatory visits of $€ 350,793,740$ and $€ 70,697,830$ respectively.

Hospitalization costs were estimated considering the expenditure associated with hospitalizations due to fractures and other causes (See Appendix for detail of the main DRGs registered) of the patients selected by the HDR database (Table 2). 
Table 2 - Average number of subjects with osteoporosis and hospitalizations due to fractures or other causes - HDR database analysis 2008-2016

\begin{tabular}{|cccccc|}
\hline Age groups & $\begin{array}{c}\text { Subjects with } \\
\text { osteoporosis }\end{array}$ & $\begin{array}{c}\text { Hospitalizations } \\
\text { due to fractures }\end{array}$ & $\begin{array}{c}\text { Other } \\
\text { hospitalizations }\end{array}$ & $\begin{array}{c}\text { Average } \\
\text { hospitalizations } \\
\text { per patient } \\
\text { (hospitalizations } \\
\text { due to fractures) }\end{array}$ & $\begin{array}{c}\text { Average } \\
\text { hospitalizations } \\
\text { per patient (other } \\
\text { hospitalizations) }\end{array}$ \\
\hline$<60$ & 4,245 & 392 & 7,627 & 0.09 & 1.80 \\
\hline $60-74$ & 62,685 & 58,195 & 52,558 & 0.93 & 0.84 \\
\hline $75+$ & 140,953 & 145,374 & 110,750 & 1.03 & 0.79 \\
\hline Total & $\mathbf{2 0 7 , 8 8 4}$ & $\mathbf{2 0 3 , 9 6 1}$ & $\mathbf{1 7 0 , 9 3 5}$ & $\mathbf{0 . 9 8}$ & $\mathbf{0 . 8 2}$ \\
\hline
\end{tabular}

The average annual cost of hospitalizations, obtained as the average value of the estimated costs for each year of analysis (2008-2016), was equal to $€ 1,785,874,284$. $63 \%$ of this cost ( $€$ $1,120,328,011)$ was attributable to hospitalizations for fractures, while the remaining $37 \%$ ( $€$ $665,546,274)$ for causes other than fractures. The average annual cost per patient with osteoporosis was $€ 8,591$.

The highest average annual cost of hospitalization per patient was recorded for patients aged over 75 years $(€ 9,050)$, followed by the average cost per patient in the 60 -74 age group $(€ 7,734)$ and the average cost per patient aged under 60 years $(€ 5,991)$ (Figure 2$)$.

Figure 2 - Hospitalization expense by age group

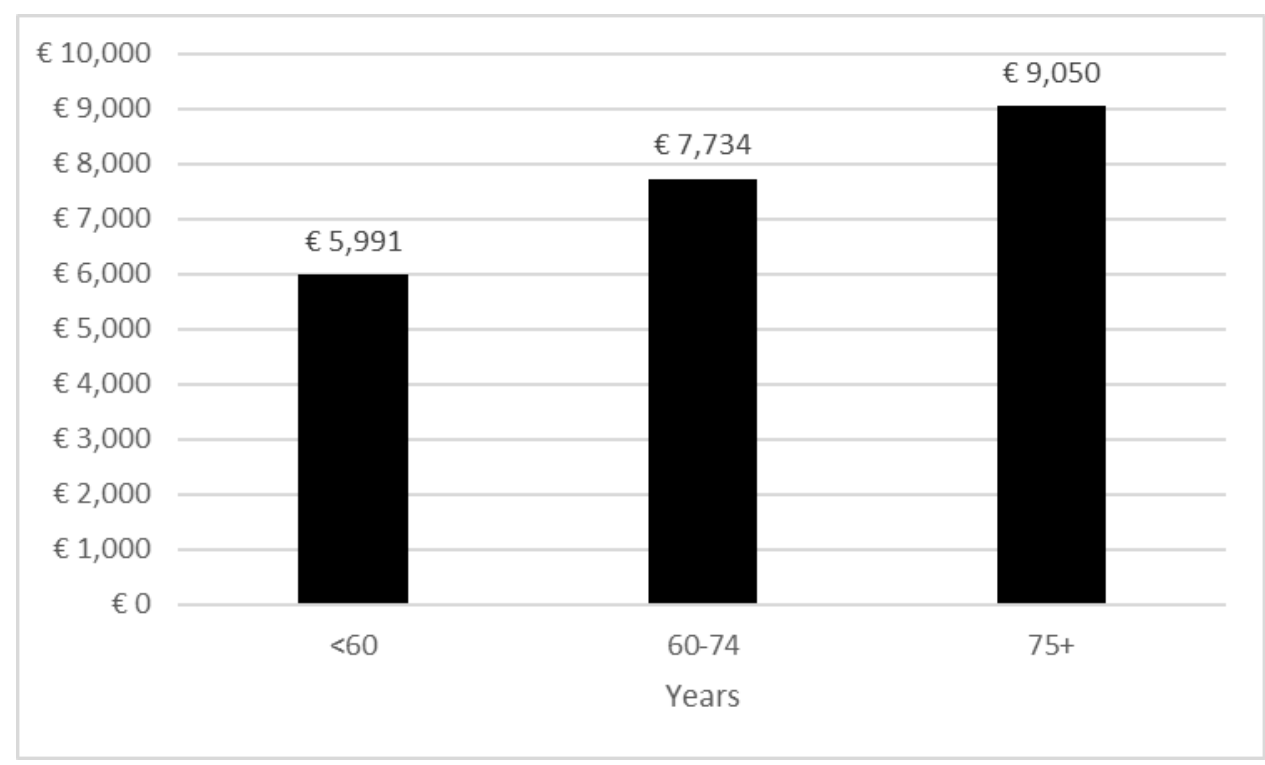

The average annual cost per patient with osteoporosis in terms of direct costs was $€ 8,688$; about $81 \%$ of this average cost was attributable to hospitalizations $(€ 8,591)$, while about $16 \%$ and $3 \%$ to pharmacological treatment and ambulatory visits respectively. 
The identification of the applications accepted by DB and IP through the ICD9 codes, according to the inclusion criteria described above, has identified an average annual number of beneficiaries equal to 1,528 (1,422 beneficiaries of DB and 106 beneficiaries of IP) and an average annual cost of $€ 13,377,798$ (Table 3), estimated for the period 2009-2015. 90\% of this average cost was characterized by the payment of DB (Table 4). In particular, $83 \%(€ 11,155,565)$ of the estimated national average annual cost was characterized by social security costs related to osteoporosis-and/or fracture-diagnosed patients in primary or secondary diagnosis, presenting other diseases in primary or secondary diagnosis. The remaining $17 \%(€ 2,222,233)$ was due to costs related to patients with osteoporosis-and/or fracture in primary or secondary diagnosis with no other comorbidity.

Table 3 - Social security costs and number of beneficiaries (Italy 2009-2015)

\begin{tabular}{|cccc|}
\hline & $\begin{array}{c}\text { Total costs } \\
\mathbf{2 0 0 9 - 2 0 1 5}\end{array}$ & $\begin{array}{c}\text { Average annual } \\
\text { beneficiaries }\end{array}$ & Average annual costs \\
\hline DB & $€ 84,052,611$ & 1,422 & $€ 12,007,516$ \\
IP & $€ 9,591,974$ & 106 & $€ 1,370,282$ \\
Total & $€ 93,644,585$ & $\mathbf{1 , 5 2 8}$ & $€ 13,377,798$ \\
\hline DB = Disability Benefits; IP = Incapacity Pension & &
\end{tabular}

\subsection{Italy CoI}

The model estimated a total cost for osteoporosis in Italy in 2017 of about $€ 2.2$ billion, of which $99.4 \%$ was characterized by direct costs. Table 4 reports the estimated national annual average, minimum and maximum (considering the variability registered in the literature and from the administrative databases) annual costs, and the percentage distribution for each cost item considered in the analysis.

Table 4 - 2017 Col of osteoporosis in Italy

\begin{tabular}{|lcccc|} 
& $\begin{array}{c}\text { Average annual cost in } \\
\text { Italy }\end{array}$ & Min & Max & Percentage \\
\hline Pharmacological treatment & $€ 350,793,740$ & $€ 344,790,997$ & $€ 453,386,587$ & $15.93 \%$ \\
Ambulatory visits & $€ 70,697,830$ & $€ 69,488,056$ & $€ 91,374,058$ & $3.21 \%$ \\
Hospitalizations & $€ 1,785,874,284$ & $€ 1,651,198,711$ & $€ 1,898,846,999$ & $80.26 \%$ \\
Social security system & $€ 13,377,798$ & $€ 9,981,115$ & $€ 18,249,383$ & $0.60 \%$ \\
Total Cost & $€ \mathbf{2 , 2 2 0 , 7 4 3 , 6 5 3}$ & $€ \mathbf{2 , 0 7 5 , 4 5 8 , 8 7 9}$ & $€ \mathbf{2 , 4 6 1 , 8 5 7 , 0 2 7}$ & $\mathbf{1 0 0 \%}$ \\
\hline
\end{tabular}




\section{Focus on patients with severe osteoporosis}

The average annual number of hospitalizations due to fractures in patients with severe osteoporosis was 33,150, while the average annual number of hospitalizations for reasons other than fracture was 16,131. The average annual cost associated with admissions of patients with severe osteoporosis was $€ 223,257,024$, of which $70 \%$ ( $€ 156,389,721)$ was attributable to hospitalizations for fractures and 30\% $(€ 66,867,303)$ to hospitalizations for other causes. Figure 4 reports the average annual costs associated with hospitalizations for fractures and hospitalizations for other causes estimated for each year of analysis.

The average annual cost associated with hospitalizations for patients with severe osteoporosis was $€ 12,336$, thus higher $(+€ 3,745)$ than that estimated for a patient with non-severe osteoporosis (€ 8,591).

Figure 4 - Average annual costs associated with patients with severe osteoporosis

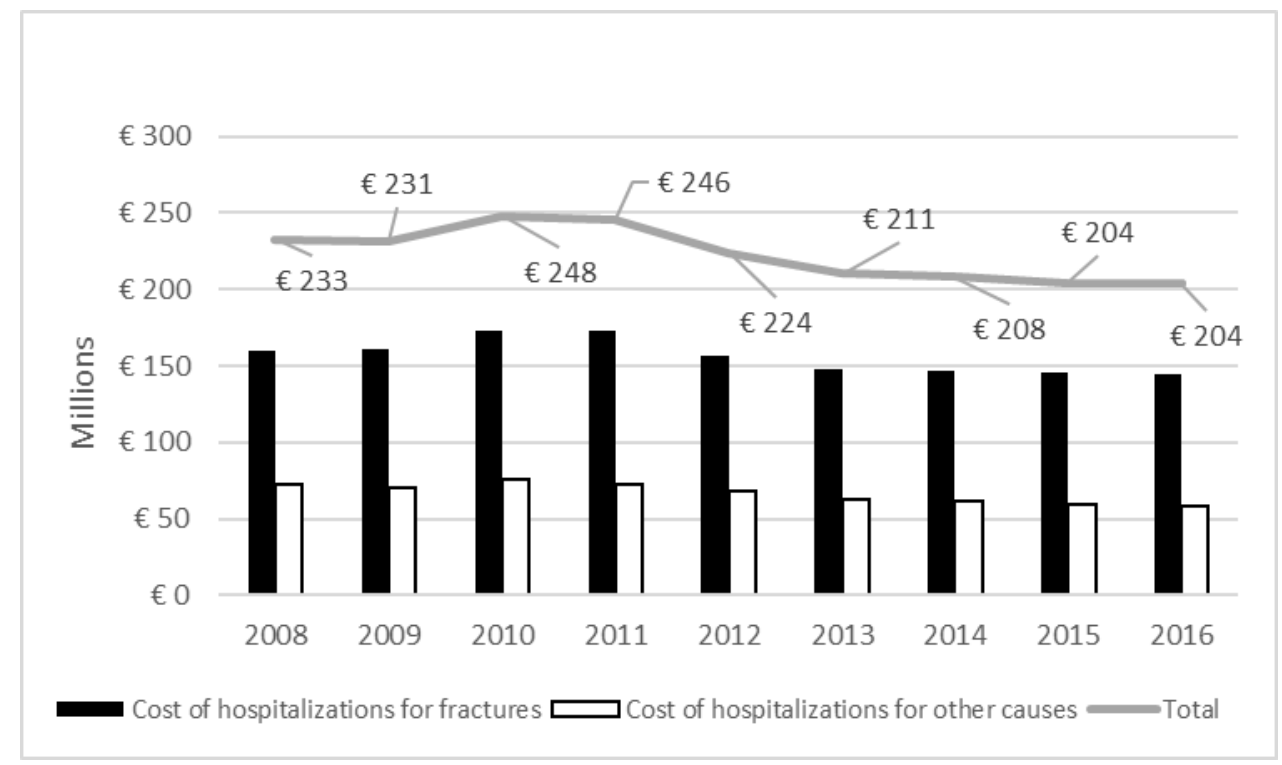




\section{Discussion}

Today osteoporosis is the most common bone disease and represent a socially relevant public health problem in all developed countries [8]. However, there are currently no studies in the literature that have attempted to quantify the cost of osteoporosis, going beyond the quantification of costs directly related to the diagnosis and treatment of the disease. As a result, although this analysis (as it will be shown in the presentation of the limitations of the study) most likely tends to underestimate the overall economic burden of the disease, it estimates the costs from a broader perspective than in previous studies [14].

In addition to the information found in the literature on drug costs and ambulatory visits, this analysis has allowed to include the costs of hospitalizations, estimated thanks to the consultation of the national HDR database, and social security costs, obtained through the administrative database of the National Social Security Institute.

In fact, although social security costs represent a very small part of the total cost quantified in this study, they have increased over the years (especially with regard to Ordinary Disability Allowances).

The analysis resulted in a total disease cost of more than $€ 2$ billion in 2017 , about $99 \%$ of which is made up of direct health costs. Among the items considered (pharmacological treatment, ambulatory visits and hospitalizations), the cost of hospitalizations, amounting to about $€ 1.8$ billion (approximately $80 \%$ of the total direct health costs), was the cost weighing more on the total. This is most likely due to the longer average length of hospitalization time of a patient with osteoporosis than that of other chronic diseases - fractures (especially femoral/hip ones) require longer rehabilitation time - and to the costs for prostheses, which are frequent for the treatment of hip fractures.

The costs associated with pharmacological treatments (basically aimed at reducing the risk of fractures) and ambulatory visits amounted to about $€ 351$ million (approximately $16 \%$ of the total) and about $€ 71$ million (about $3 \%$ of the total) respectively.

Social security costs, which accounted for only $0.6 \%$ of the total costs associated with osteoporosis, amounted to about $€ 13$ million, of which approximately $89 \%$ was characterised by costs relating to the payment of $\mathrm{DB}$.

The study is not without limitations. First of all, the costs of fragility fractures that do not involve hospitalization have not been considered because they are managed only in the emergency department or they are not treated at all, as it often happens for spinal fractures. Secondly, some cost items associated with the disease, such as indirect costs for patients or caregivers (i.e. costs related to the loss of productivity at work due to the disease) have not been estimated. Indeed, the management and drug treatment didn't remain the same over the 5 years considered in the analysis. However, these 
costs may not represent a high share of the total cost because osteoporosis mainly affects aged people and therefore no longer in working age ( $2 \%$ of the HDR analysis had an age lower than 60 years).

Finally, the databases consulted are administrative and not clinical. Therefore, it has not been possible to carry out a breakdown of patients according to the disease severity, as these databases do not take into account the risk factors that may affect hospitalizations.

Considering the above limitations, we can, therefore, state that the analysis conducted tends to underestimate the overall economic burden of osteoporosis.

\section{Conclusions}

This Cost of Illness (CoI) study was conducted in order to quantify the overall burden of the patients suffering from osteoporosis in Italy from the perspective of the NHS and that of the social security system. This cost was equal to $€ 2,220,743,653$ in 2017 , demonstrating that osteoporosis represents a significant health problem because it generates a high economic burden, especially in terms of hospitalization. In particular, most of the estimated costs were due to hospitalizations because an osteoporotic patient who experiences a bone fracture, especially a hip fracture, encounters medium-long hospitalization time due, above all, to the time of post-operative rehabilitation. Moreover, it was shown that hospitalization costs increase in patients with severe osteoporosis $(+$ $€ 3,745$ ( $+44 \%)$ compared to the estimated average annual cost for a patient with non-severe osteoporosis). 


\section{Appendix}

Tabella 1 - DRGs considered

\begin{tabular}{|c|c|c|}
\hline DRG & Description & $\%$ \\
\hline 249 & AFTERCARE, MUSCULOSKELETAL SYSTEM \& CONNECTIVE TISSUE & 9,4 \\
\hline 127 & HEART FAILURE \& SHOCK & 4,8 \\
\hline 087 & PULMONARY EDEMA \& RESPIRATORY FAILURE & 3,4 \\
\hline 256 & OTHER MUSCULOSKELETAL SYSTEM \& CONNECTIVE TISSUE DIAGNOSIS & 3,4 \\
\hline 245 & BONE DISEASES \& SPECIFIC ARTHROPATHIES WITHOUT COMPLICATIONS, COMORBIDITIES & 2,2 \\
\hline 012 & DEGENERATIVE NERVOUS SYSTEM DISORDERS & 2,1 \\
\hline 088 & CHRONIC OBSTRUCTIVE PULMONARY DISEASE & 1,8 \\
\hline 089 & SIMPLE PNEUMONIA \& PLEURISY AGE >17 WITH COMPLICATIONS, COMORBIDITIES & 1,8 \\
\hline 538 & $\begin{array}{l}\text { LOCAL EXCISION AND REMOVAL OF INTERNAL FIXATION DEVICES EXCEPT HIP AND FEMUR } \\
\text { WITHOUT CC (added 10-1-03) }\end{array}$ & 1,7 \\
\hline 014 & $\begin{array}{l}\text { INTRA CRANIAL HEMORRHAGE AND STROKE WITH INFARCTION (beginning 10-1-02, used to 10-1- } \\
\text { 04) }\end{array}$ & 1,6 \\
\hline 410 & CHEMOTHERAPY WITHOUT ACUTE LEUKEMIA AS SECONDARY DIAGNOSIS & 1,5 \\
\hline 316 & RENAL FAILURE & 1,5 \\
\hline 395 & RED BLOOD CELL DISORDERS AGE >17 & 1,5 \\
\hline 247 & SIGNS \& SYMPTOMS OF MUSCULOSKELETAL SYSTEM \& CONNECTIVE TISSUE & 1,4 \\
\hline 243 & MEDICAL BACK PROBLEMS & 1,3 \\
\hline 544 & MAJOR JOINT REPLACEMENT OR REATTACHMENT OF LOWER EXTREMITY (added 10-1-05) & 1,3 \\
\hline 239 & PATHOLOGICAL FRACTURES \& MUSCULOSKELETAL \& CONNECTIVE TISSUE MALIGNANCY & 1,3 \\
\hline 576 & SEPTICEMIA W MECHANICAL VENTILATOR W/0 96+ HOURS AGE >17 (added 10-1-06) & 1,2 \\
\hline 462 & REHABILITATION & 1,1 \\
\hline 241 & CONNECTIVE TISSUE DISORDERS WITHOUT COMPLICATIONS, COMORBIDITIES & 1,1 \\
\hline 240 & CONNECTIVE TISSUE DISORDERS WITH COMPLICATIONS, COMORBIDITIES & 1,0 \\
\hline 244 & BONE DISEASES \& SPECIFIC ARTHROPATHIES WITH COMPLICATIONS, COMORBIDITIES & 1,0 \\
\hline 234 & $\begin{array}{l}\text { OTHER MUSCULOSKELETAL SYSTEM \& CONNECTIVE TISSUE OPERATING ROOM PROCEDURES } \\
\text { WITHOUT COMPLICATIONS, COMORBIDITIES }\end{array}$ & 1,0 \\
\hline 202 & CIRRHOSIS \& ALCOHOLIC HEPATITIS & 1,0 \\
\hline 524 & TRANSIENT ISCHEMIA (added 10-1-02) & 1,0 \\
\hline 467 & OTHER FACTORS INFLUENCING HEALTH STATUS & 0,9 \\
\hline 039 & LENS PROCEDURES WITH OR WITHOUT VITRECTOMY & 0,8 \\
\hline 296 & $\begin{array}{l}\text { NUTRITIONAL \& MISCELLANEOUS METABOLIC DISORDERS AGE >17 WITH COMPLICATIONS, } \\
\text { COMORBIDITIES }\end{array}$ & 0,7 \\
\hline 183 & $\begin{array}{l}\text { ESOPHAGITIS, GASTROENTERITIS, \& MISCELLANEOUS DIGESTIVE DISORDERS AGE > } 17 \text { WITHOUT } \\
\text { COMPLICATIONS, COMORBIDITIES }\end{array}$ & 0,7 \\
\hline 248 & TENDINITIS, MYOSITIS \& BURSITIS & 0,7 \\
\hline 429 & ORGANIC DISTURBANCES \& MENTAL RETARDATION & 0,6 \\
\hline 182 & $\begin{array}{l}\text { ESOPHAGITIS, GASTROENTERITIS, \& MISCELLANEOUS DIGESTIVE DISORDERS AGE >17 WITH } \\
\text { COMPLICATIONS, COMORBIDITIES }\end{array}$ & 0,6 \\
\hline 082 & RESPIRATORY NEOPLASMS & 0,6 \\
\hline 466 & AFTERCARE WITHOUT HISTORY OF MALIGNANCY AS SECONDARY DIAGNOSIS & 0,6 \\
\hline 015 & $\begin{array}{l}\text { NONSPECIFIC CEREBROVASCULAR AND PRECEREBRAL OCCLUSION WITHOUT INFARCTION } \\
\text { (beginning 10-1-02) }\end{array}$ & 0,5 \\
\hline 090 & SIMPLE PNEUMONIA \& PLEURISY AGE >17 WITHOUT COMPLICATIONS, COMORBIDITIES & 0,5 \\
\hline 138 & CARDIAC ARRHYTHMIA \& CONDUCTION DISORDERS WITH COMPLICATIONS, COMORBIDITIES & 0,5 \\
\hline 035 & OTHER DISORDERS OF NERVOUS SYSTEM WITHOUT COMPLICATION, COMORBIDITIES & 0,5 \\
\hline
\end{tabular}




\begin{tabular}{|c|c|c|}
\hline 174 & GASTROINTESTINAL HEMORRHAGE WITH COMPLICATIONS, COMORBIDITIES & 0,5 \\
\hline 203 & MALIGNANCY OF HEPATOBILIARY SYSTEM OR PANCREAS & 0,5 \\
\hline 139 & CARDIAC ARRHYTHMIA \& CONDUCTION DISORDERS WITHOUT COMPLICATIONS, COMORBIDITIES & 0,5 \\
\hline 016 & NONSPECIFIC CEREBROVASCULAR DISORDERS WITH COMPLICATIONS, COMORBIDITIES & 0,5 \\
\hline 134 & HYPERTENSION & 0,5 \\
\hline 297 & $\begin{array}{l}\text { NUTRITIONAL \& MISCELLANEOUS METABOLIC DISORDERS AGE >17 WITHOUT COMPLICATIONS, } \\
\text { COMORBIDITIES }\end{array}$ & 0,5 \\
\hline 144 & OTHER CIRCULATORY SYSTEM DIAGNOSES WITH COMPLICATIONS, COMORBIDITIES & 0,5 \\
\hline 078 & PULMONARY EMBOLISM & 0,5 \\
\hline 320 & KIDNEY \& URINARY TRACT INFECTIONS AGE >17 WITH COMPLICATIONS, COMORBIDITIES & 0,5 \\
\hline 430 & PSYCHOSES & 0,5 \\
\hline 294 & DIABETES AGE >35 & 0,4 \\
\hline 404 & LYMPHOMA \& NON-ACUTE LEUKEMIA WITHOUT COMPLICATIONS, COMORBIDITIES & 0,4 \\
\hline 403 & LYMPHOMA \& NON-ACUTE LEUKEMIA WITH COMPLICATIONS, COMORBIDITIES & 0,4 \\
\hline 017 & NONSPECIFIC CEREBROVASCULAR DISORDERS WITHOUT COMPLICATIONS, COMORBIDITIES & 0,4 \\
\hline 216 & BIOPSIES OF MUSCULOSKELETAL SYSTEM \& CONNECTIVE TISSUE & 0,4 \\
\hline 207 & DISORDERS OF THE BILIARY TRACT WITH COMPLICATIONS, COMORBIDITIES & 0,4 \\
\hline 545 & REVISION OF HIP OR KNEE REPLACEMENT (added 10-1-05) & 0,4 \\
\hline 205 & $\begin{array}{l}\text { DISORDERS OF LIVER EXCEPT MALIGNANCY, CIRRHOSIS, ALCOHOLIC HEPATITIS WITH } \\
\text { COMPLICATIONS, COMORBIDITIES }\end{array}$ & 0,4 \\
\hline 266 & $\begin{array}{l}\text { SKIN GRAFT \&/OR DEBRIDEMENT EXCEPT FOR SKIN ULCER OR CELLULITIS WITHOUT } \\
\text { COMPLICATIONS, COMORBIDITIES }\end{array}$ & 0,4 \\
\hline 130 & PERIPHERAL, VASCULAR DISORDERS WITH COMPLICATIONS, COMORBIDITIES & 0,4 \\
\hline 181 & GASTROINTESTINAL OBSTRUCTION WITHOUT COMPLICATIONS, COMORBIDITIES & 0,3 \\
\hline 552 & OTHER PERMANENT CARDIAC PACEMAKER IMPLANT WITHOUT MCV DIAGNOSIS (added 10-1-05) & 0,3 \\
\hline 034 & OTHER DISORDERS OF NERVOUS SYSTEM WITH COMPLICATIONS, COMORBIDITIES & 0,3 \\
\hline 301 & ENDOCRINE DISORDERS WITHOUT COMPLICATIONS, COMORBIDITIES & 0,3 \\
\hline 321 & KIDNEY \& URINARY TRACT INFECTIONS AGE >17 WITHOUT COMPLICATIONS, CON & 0,3 \\
\hline 233 & $\begin{array}{l}\text { OTHER MUSCULOSKELETAL SYSTEM \& CONNECTIVE TISSUE OPERATING ROOM PROCEDURES WITH } \\
\text { COMPLICATIONS, COMORBIDITIES }\end{array}$ & 0,3 \\
\hline 180 & GASTROINTESTINAL OBSTRUCTION WITH COMPLICATIONS, COMORBIDITIES & 0,3 \\
\hline 009 & SPINAL DISORDERS \& INJURIES & 0,3 \\
\hline 042 & INTRAOCULAR PROCEDURES EXCEPT RETINA, IF & 0,3 \\
\hline 079 & RESPIRATORY INFECTIONS \& INFLAMMATIONS AGE >17 WITH COMPLICATIONS, COMORBIDITIES & 0,3 \\
\hline 230 & LOCAL EXCISION \& REMOVAL OF INTERNAL FIXATION DEVICES OF HIP \& FEMUR & 0,3 \\
\hline 208 & DISORDERS OF THE BILIARY TRACT WITHOUT COMPLICATIONS, COMORBIDITIES & 0,3 \\
\hline 131 & PERIPHERAL VASCULAR DISORDERS WITHOUT COMPLICATIONS, COMORBIDITIES & 0,3 \\
\hline 085 & PLEURAL EFFUSION WITH COMPLICATIONS, COMORBIDITIES & 0,3 \\
\hline 125 & $\begin{array}{l}\text { CIRCULATORY DISORDERS EXCEPT ACUTE MYOCARDIAL INFARCTION, WITH CARDIAC CATHETER } \\
\text { WITHOUT COMPLEX DIAGNOSES }\end{array}$ & 0,3 \\
\hline 172 & DIGESTIVE MALIGNANCY WITH COMPLICATIONS, COMORBIDITIES & 0,3 \\
\hline 132 & ATHEROSCLEROSIS WITH COMPLICATIONS, COMORBIDITIES & 0,3 \\
\hline 463 & SIGNS \& SYMPTOMS WITH COMPLICATIONS, COMORBIDITIES & 0,3 \\
\hline 121 & $\begin{array}{l}\text { CIRCULATORY DISORDERS WITH ACUTE MYOCARDIAL INFARCTION \& MAJOR COMPLICATION, } \\
\text { DISCHARGED ALIVE (beginning 10-1-97) }\end{array}$ & 0,3 \\
\hline 162 & $\begin{array}{l}\text { INGUINAL \& FEMORAL HERNIA PROCEDURES AGE >17 WITHOUT COMPLICATIONS, } \\
\text { COMORBIDITIES }\end{array}$ & 0,3 \\
\hline 145 & OTHER CIRCULATORY SYSTEM DIAGNOSES WITHOUT COMPLICATIONS, COMORBIDITIES & 0,3 \\
\hline 271 & SKIN ULCERS & 0,3 \\
\hline
\end{tabular}




\begin{tabular}{|l|l|c|}
311 & TRANSURETHRAL PROCEDURES WITHOUT COMPLICATIONS, COMORBIDITIES & 0,3 \\
\hline 143 & CHEST PAIN & 0,3 \\
\hline 141 & SYNCOPE \& COLLAPSE WITH COMPLICATIONS, COMORBIDITIES & 0,2 \\
\hline 470 & UNGROUPABLE & 0,2 \\
\hline 142 & SYNCOPE \& COLLAPSE WITHOUT COMPLICATIONS, COMORBIDITIES & 0,2 \\
\hline 122 & $\begin{array}{l}\text { CIRCULATORY DISORDERS WITH ACUTE MYOCARDIAL INFARCTION WITHOUT MAJOR } \\
\text { COMPLICATION, DISCHARGED ALIVE (beginning 10-1-97) }\end{array}$ & 0,2 \\
\hline 423 & OTHER INFECTIOUS \& PARASITIC DISEASES DIAGNOSES & 0,2 \\
\hline 566 & RESPIRATORY SYSTEM DIAGNOSIS WITH VENTILATOR SUPPORT <96 HRS (added 10-1-06) & 0,2 \\
\hline 175 & GASTROINTESTINAL HEMORRHAGE WITHOUT COMPLICATIONS, COMORBIDITIES & 0,2 \\
\hline 246 & NON-SPECIFIC ARTHROPATHIES & 0,2 \\
\hline 189 & OTHER DIGESTIVE SYSTEM DIAGNOSES AGE >17 WITHOUT COMPLICATIONS, COMORBIDITIES & 0,2 \\
\hline 140 & ANGINA PECTORIS & 0,2 \\
\hline 204 & DISORDERS OF PANCREAS EXCEPT MALIGNANCY & 0,2 \\
\hline 231 & LOCAL EXCISION \& REMOVAL OF INTERNAL FIXATION DEVICES (NO HIP \& FEMUR) & 0,2 \\
\hline 029 & TRAUMATIC STUPOR \& COMA, COMA <1 HR AGE >17 WITHOUT COMPLICATIONS, COMORBIDITIES & 0,2 \\
\hline 479 & OTHER VASCULAR PROCEDURES WITHOUT COMPLICATIONS, CORMORBIDITIES & 0,2 \\
\hline 300 & ENDOCRINE DISORDERS WITH COMPLICATIONS, COMORBIDITIES & 0,2 \\
\hline 019 & CRANIAL \& PERIPHERAL NERVE DISORDERS WITHOUT COMPLICATIONS, COMORBIDITIES & 0,2 \\
\hline 572 & MAJOR GASTROINTESTINAL DISORDERS AND PERITONEAL INFECTIONS (added 10-1-06) & 0,2 \\
\hline 099 & RESPIRATORY SIGNS \& SYMPTOMS WITH COMPLICATIONS, COMORBIDITIES & 0,2 \\
\hline
\end{tabular}




\section{References}

1. Nuti, R., et al., Guidelines for the management of osteoporosis and fragility fractures. Intern Emerg Med, 2019. 14(1): p. 85-102.

2. Societa Italiana dell'Osteoporosi, d.M.M.e.d.M.d.S., [Guidelines for the diagnosis, prevention and treatment of osteoporosis. Italian Osteoporosis, Mineral Metabolism, and Skeletal Diseases Society]. Minerva Endocrinol, 2013. 38(1 Suppl 1): p. 1-30.

3. National Institute of Arthritis and Musculoskeletal and Skin Diseases. Osteoporosis in Men. Available from: https://www.bones.nih.gov/health-info/bone/osteoporosis/men.

4. American Society for Bone and Mineral Research, Primer on the Metabolic Bone Diseases and Disorders of Mineral Metabolism. Seventh ed. 2008.

5. Marcus R, et al., Osteoporosis Third ed. 2007.

6. Albanese CV and Passariello R, Osteoporosi e Malattie Metaboliche dell'Osso. Clinica e Diagnostica. Second ed. 2009.

7. Curtis, E.M., et al., Epidemiology of fractures in the United Kingdom 1988-2012: Variation with age, sex, geography, ethnicity and socioeconomic status. Bone, 2016. 87: p. 19-26.

8. Cipriani, C., et al., The epidemiology of osteoporosis in Italian postmenopausal women according to the National Bone Health Alliance (NBHA) diagnostic criteria: a multicenter cohort study. J Endocrinol Invest, 2018. 41(4): p. 431-438.

9. Kalos MH. and Whitlock PA., Monte Carlo Methods. Second, revised and enlarged ed. 2008.

10. Camera dei deputati e Senato della Repubblica, Revisione della disciplina della invalidità pensionabile, in LEGGE 12 giugno 1984, n. 222. 1984.

11. Maggi, S., et al., Quantitative heel ultrasound in a population-based study in Italy and its relationship with fracture history: the ESOPO study. Osteoporos Int, 2006. 17(2): p. 237-44.

12. Hernlund, E., et al., Osteoporosis in the European Union: medical management, epidemiology and economic burden. A report prepared in collaboration with the International Osteoporosis Foundation (IOF) and the European Federation of Pharmaceutical Industry Associations (EFPIA). Arch Osteoporos, 2013. 8: p. 136.

13. Istat. 2018 2nd february 2019]; Available from: http://demo.istat.it/pop2017/index.html.

14. Degli Esposti L. et al., Cost of osteoporosis-related fracture in Italy. Results of the BLOCK study. 2011.

15. Svedbom, A., et al., Osteoporosis in the European Union: a compendium of country-specific reports. Arch Osteoporos, 2013. 8: p. 137.

16. Salomon, J.A., et al., Cost-effectiveness of treatment for chronic hepatitis $C$ infection in an evolving patient population. JAMA, 2003. 290(2): p. 228-37. 